\title{
Research on Technological Innovation Capability of Manufacturing Industry
}

\author{
Tao Zhang ${ }^{1, \text { a * }}$ \\ ${ }^{1}$ Shanghai University, China \\ azhangtao1672@163.com
}

\begin{abstract}
Keywords: Manufacturing industry; Technological innovation ability; Factor analysis; Anhui Province
\end{abstract}

\begin{abstract}
At present, the country vigorously promotes the transformation and upgrading of the manufacturing industry. Manufacturing industry acquires a development opportunity in Anhui province. On the basis of summarizing the concept of technological innovation, the research methods of manufacturing technological innovation ability and the predecessors' research on manufacturing technological innovation ability, this paper research the development level of technology innovation ability of manufacturing industry in Anhui province. By using factor analysis model, this paper constructs the evaluation index hierarchy to estimate technological innovation ability of manufacturing industry in Anhui province. This article analysis the technology innovation ability of 29 sub-sectors of the manufacturing industry from the following three aspects: innovation input ability, innovation basic environment and innovation output capability. Finally, in view of the characteristics and the existing problems of the development of manufacturing industry innovation in Anhui province, this paper puts forward reasonable policy recommendations.
\end{abstract}

\section{Introduction}

Schumpeter, an economist who first studied technological innovation, believed that innovation was the introduction of a new combination of factors of production and production conditions that had never existed before into the production system [1]. In 1957, American economist Solow scientifically measured the contribution of technological innovation to economic growth, and affirmed the important role of technological innovation in promoting economic growth . In 1982, C. Freeman published a revised edition of the Economics of Industrial Innovation, in which he defined technological innovation as the first commercial transformation of new products, processes, systems and equipment [2]. Professor J.J. Fu of Tsinghua University, who made outstanding contributions to the domestic research, pointed out that technological innovation means that entrepreneurs should seize the potential profit opportunities of the market, reorganize production conditions and factors, and establish more efficient and efficient production with the goal of gaining commercial benefits. High and low-cost production and operation systems, thereby introducing new products, new production methods, opening up new markets, obtaining new sources of raw materials or semi-finished products, or establishing new organizations for enterprises, include a comprehensive process of a range of activities, including science, technology, organization, commerce and finance [3]. In 2015, the State Council issued Made in China 2025, which defined a national strategy for the transformation and upgrading of traditional manufacturing industries. Anhui provincial government actively responded to the call of the state, formulated a series of industrial development policies, and strived to improve the level of technological innovation in manufacturing industry.

\section{Literature Review}

Manufacturing industry, as an important part of the real economy, has always been the focus of academic research. B.N. Fan, S.T. Shan and C.S. Lu (2002) constructed the evaluation index system of urban technological innovation ability [4]. L.S. Li and Y. Zhou (2005) used correlation analysis method and expert consultation method to design an evaluation system with 19 indicators, reflecting the strength, potential, supporting capacity and institutional capacity of technological innovation [5]. 
H.F. Yang and B. Shen (2007) considered the basic environment of innovation, the ability to invest in science and technology, and the environmental support capacity of innovation. The evaluation system of technological innovation capability of equipment manufacturing industry is established, which includes 42 specific indicators of qualitative and quantitative aspects [6]. R.G. Zheng (2010) used factor analysis to study the innovative ability of 29 sub-sectors of China's manufacturing industry in 2007[7]. T.S. Zhang and H.W. Xiao (2015) set up the evaluation index system of innovation ability including nine specific indexes from two aspects of innovation input and output, and used factor analysis method to evaluate the innovation ability of 30 subdivisions of China's manufacturing industry. The technology industry is weak [8]. L.C. Huang, H.C. Zhang and X.Y. Li (2005) used factor analysis model to analyze and evaluate 18 manufacturing industries in Beijing on the basis of summarizing scholars' understanding of innovation ability. The results show that innovation input is the main factor affecting the technological innovation ability of manufacturing industry [9].

\section{Data}

This paper selects 29 sub sectors of manufacturing industry in Anhui Province as the research object, and selects 2014 during the study period. Due to the lack of scientific and technological statistical data in Anhui Province, considering the principles of science and feasibility, we study the statistical data of Industrial Enterprises above the scale. The main data sources are as follows: Anhui Statistical Yearbook 2015, Anhui Statistical Bureau official website; Anhui Statistical Bureau cultural office. Referring to B.M. Chen's (2006) research [10], the evaluation index system of Anhui manufacturing technology innovation capability is formed, which includes three first-level indicators of innovation input, innovation foundation, innovation output and ten second-level indicators.

Table 1 Evaluation index system of technological innovation capability

\begin{tabular}{cc}
\hline First level index & Two level index \\
\hline \multirow{3}{*}{ Investment } & R\&D personnel ratio [\%] \\
& R\&D funding intensity[\%] \\
& Proportion of purchase of equipment and equipment[\%] \\
& Proportion of new product research funds[\%] \\
& Average number of invention patents owned by enterprises \\
Foundationof & Average number of scientific institutions in enterprises \\
& Per capita patent applications \\
Output & Number of invention patents per capita \\
& Output value of new products [\%] \\
& Sales revenue of new products [\%]
\end{tabular}

\section{Empirical Result and Analysis}

Correlation test. Firstly, SPSS 20 is used to test the correlation of the data. The most commonly tests are Bartlett sphericity test and KMO test. The result of KMO test is 0.73 which is exceeded 0.7 , indicating that the data are suitable for factor analysis. The result of Bartlett's sphericity test shows that the approximate chi-square is 282.57 , the degree of freedom is 28 , and the P-value is less than 0.0005 . There is a strong correlation between the data, which is suitable for factor analysis.

Extract Common Factor. The common factor is extracted by principal component analysis, and three principal components are extracted according to the principle that the eigenvalue is greater than 1. The cumulative variance contribution rate reaches $89.029 \%$, which retains most of the original data. According to the factor load matrix after rotation, factor 1 is named innovation input and new product output factor; factor 2 is named innovation foundation factor; factor 3 is named patent output factor 
Factor Analysis. SPSS20 can directly calculate each factor score taken from the cumulative variance contribution rate after their respective rotation. The final factor scores and the overall score are as follows.

Table 2 Factor score and ranking

\begin{tabular}{|c|c|c|c|c|c|c|c|c|}
\hline Industry & FAC1 & Rank & FAC2 & Rank & FAC3 & Rank & Score & Rank \\
\hline $\begin{array}{l}\text { Agricultural and sideline } \\
\text { products }\end{array}$ & -0.50 & 21 & -0.57 & 22 & 0.87 & 3 & -0.20 & 17 \\
\hline Food & -0.38 & 20 & -0.31 & 13 & 2.63 & 2 & 0.33 & 10 \\
\hline Wine, beverage and refined tea & -0.38 & 19 & -0.32 & 14 & -0.49 & 21 & -0.39 & 21 \\
\hline Tobacco products & -1.58 & 29 & 4.14 & 1 & 0.36 & 6 & 0.19 & 12 \\
\hline textile & -0.79 & 23 & -0.56 & 21 & -0.56 & 23 & -0.68 & 25 \\
\hline Textile and clothing & -1.34 & 27 & -0.74 & 27 & -0.50 & 22 & -1.00 & 29 \\
\hline $\begin{array}{l}\text { Leather, fur, feathers and their } \\
\text { products and footwear }\end{array}$ & -0.96 & 26 & -0.46 & 17 & 0.05 & 9 & -0.61 & 24 \\
\hline $\begin{array}{l}\text { Wood processing and wood, } \\
\text { bamboo, rattan, brown and } \\
\text { grass products }\end{array}$ & -0.96 & 25 & -0.73 & 26 & 0.33 & 8 & -0.61 & 23 \\
\hline Furniture & -0.91 & 24 & -0.60 & 24 & -0.73 & 24 & -0.80 & 27 \\
\hline Paper and paper products & -0.14 & 14 & -0.85 & 29 & -0.19 & 16 & -0.31 & 20 \\
\hline $\begin{array}{l}\text { Printing and recording media } \\
\text { replication }\end{array}$ & -0.31 & 17 & -0.42 & 16 & -0.06 & 12 & -0.28 & 19 \\
\hline $\begin{array}{l}\text { Manufacturing of culture, } \\
\text { education, industry, sports and } \\
\text { entertainment products }\end{array}$ & -0.30 & 16 & -0.57 & 23 & 3.51 & 1 & 0.52 & 7 \\
\hline $\begin{array}{l}\text { Petroleum processing, coking } \\
\text { and nuclear fuel }\end{array}$ & -1.35 & 28 & 0.39 & 8 & -1.20 & 28 & -0.91 & 28 \\
\hline $\begin{array}{l}\text { Chemical raw materials and } \\
\text { chemical products }\end{array}$ & 0.46 & 9 & 0.37 & 9 & -0.42 & 20 & 0.23 & 11 \\
\hline Pharmaceutical & 0.94 & 4 & 0.95 & 3 & -0.26 & 18 & 0.67 & 5 \\
\hline Chemical fiber & 1.82 & 2 & -0.51 & 18 & -1.02 & 27 & 0.63 & 6 \\
\hline Rubber and plastic products & 0.27 & 11 & -0.53 & 20 & -0.14 & 15 & -0.01 & 14 \\
\hline Nonmetallic mineral products & -0.69 & 22 & -0.68 & 25 & -0.74 & 25 & -0.70 & 26 \\
\hline $\begin{array}{l}\text { Ferrous metal smelting and } \\
\text { calendering }\end{array}$ & -0.06 & 13 & -0.07 & 11 & -0.03 & 10 & -0.05 & 15 \\
\hline $\begin{array}{l}\text { Nonferrous metal smelting and } \\
\text { calendering }\end{array}$ & 0.75 & 7 & 0.07 & 10 & -1.29 & 29 & 0.12 & 13 \\
\hline Metal products & -0.19 & 15 & -0.34 & 15 & -0.20 & 17 & -0.22 & 18 \\
\hline General equipment & 0.44 & 10 & 0.58 & 5 & -0.07 & 13 & 0.36 & 8 \\
\hline Special equipment & 0.47 & 8 & 0.41 & 7 & -0.04 & 11 & 0.34 & 9 \\
\hline Automobile & 3.01 & 1 & -0.26 & 12 & 0.62 & 4 & 1.70 & 1 \\
\hline $\begin{array}{l}\text { Railways, ships, aerospace and } \\
\text { other transport equipment }\end{array}$ & -0.38 & 18 & -0.53 & 19 & -0.79 & 26 & -0.51 & 22 \\
\hline $\begin{array}{l}\text { Electrical machinery } \\
\text { equipment }\end{array}$ & 1.01 & 3 & 0.94 & 4 & 0.37 & 5 & 0.85 & 2 \\
\hline $\begin{array}{l}\text { Computer, communications and } \\
\text { other electronic equipment }\end{array}$ & 0.91 & 5 & 1.46 & 2 & -0.26 & 19 & 0.77 & 3 \\
\hline Instrument & 0.90 & 6 & 0.55 & 6 & 0.34 & 7 & 0.69 & 4 \\
\hline Others & 0.21 & 12 & -0.80 & 28 & -0.08 & 14 & -0.09 & 16 \\
\hline
\end{tabular}

According to the classification of manufacturing industry, manufacturing industry can be divided into light textile manufacturing industry, resource processing industry and mechanical and electronic manufacturing industry. From the perspective of innovation input and new product output factors, only the top 11 industries scored more than zero, indicating that these industries have relatively high input and new product output capacity. From the perspective of industry distribution, it is mainly concentrated on the machining and manufacturing industry and resource processing industry. From the point of view of innovation foundation factor score, the industries with factor score greater than zero are tobacco products industry, computer industry, pharmaceutical 
manufacturing industry and so on, indicating that the basic strength of innovation in these industries is higher than the average level. These industries are concentrated in the mechanical and electronic manufacturing industry and resource processing industry, and the mechanical and electronic manufacturing industry ranks relatively higher. From the point of view of the score of the patent output factor, the industries whose score is greater than zero are culture and education, industrial and aesthetic, sports and entertainment goods manufacturing, food manufacturing and agricultural and sideline food processing and so on. From the above data, we can see that the two levels of patent output differentiation are more serious, in addition to cultural and educational, industrial and aesthetic, sports and entertainment goods manufacturing (3.51), food manufacturing (2.63) score higher, the third agricultural and sideline food processing industry score only 0.87 , and the factor score of other industries is less than zero. From the perspective of industry distribution, it is mainly concentrated in the light textile manufacturing industry.

\section{Conclusion and Policy Suggestion}

From the comprehensive score, the top five industries are automobile manufacturing, electrical machinery and equipment manufacturing, computer, communications and other electronic equipment manufacturing, instrumentation manufacturing, pharmaceutical manufacturing, indicating that these industries have strong technological innovation capabilities. From the industry distribution, the top four are mechanical and electronic manufacturing. The mechanical and electronic manufacturing industry has abundant capital and obvious scale effect, which is conducive to the research of technological innovation. Ranked fifth is the pharmaceutical manufacturing industry, which belongs to the high-tech industry, and the driving force of innovation is obvious. Pharmaceutical manufacturing industry innovation input and new product output factor score fourth, innovation foundation factor score third, while patent output factor ranks 18, patent output strength is weak. Through data observation and comparison, we can find that the ranking and comprehensive ranking of innovation input and new product output factors are close, and the variance contribution rate of innovation input and new product output factors is $47.943 \%$, which shows that new input and new product output factors are the main factors affecting the innovation ability of manufacturing industry in Anhui Province.

First of all, Anhui Province should increase the investment of government funds, strengthen the government supervision of enterprise innovation activities, help enterprises to improve innovation efficiency. At the same time, tax preferential policies have a strong guiding role, which can reduce the risk and cost of technological innovation and increase enterprise income. At present, the tax exemption system in Anhui province needs further improvement and improvement. On the other hand, we should highlight the core position of enterprises' innovation. Firstly, enterprises should fully realize the important role of technological innovation for the profit growth and future sustainable development of enterprises. Only through technological innovation can we upgrade products or services, consolidate the existing market and expand market share, and then obtain new profit growth points, and achieve long-term sustainable development. Secondly, we must establish a long-term R \& D investment mode, and research and development input will be linked to the profits of enterprises. Finally, enterprises should strengthen supervision over R \& D funds and ensure that every fund is put into practice. Finally, the government should vigorously promote industry university research cooperation. Industry university research cooperation refers to the cooperation between the three enterprises, universities and research institutions. As the main body of innovation, enterprises should play a leading role in industry university research cooperation. This leading role is reflected in two aspects: on the one hand, enterprises are the main body of investment in innovation funds, in the cooperation between industry, University and research, government funds can only play a guiding and supporting role, enterprise funds play a leading role. On the other hand, the leading role of research and development, enterprises should be based on market feedback information, timely and effective research and development of institutions of higher learning and research institutions to guide improvement, which can considerably improve the economic transformation capacity of scientific research output. 


\section{Reference}

[1] Joseph Alois Schumpeter: Theory of Economic Development (Commercial Press, China 1990). (In Chinese)

[2] Freeman. Industrial Innovation Economics (Peking University press, China 2004). (In Chinese)

[3] J.J. Fu. Technology Innovation (Tsinghua University press, China 1995). (In Chinese)

[4] B.N. Fan, S.T. Shan and C.S. Lu. Scientific Research, Vol. 20 (2002) No.6, p.663. (In Chinese)

[5] L.S. Li and Y. Zhou. Science and Management of Science and Technology, Vol. 26(2005) No.3, p.38. (In Chinese)

[6] H.F. Yang and B. Shen. Industrial Technology Economy, Vol. 26 (2007) No.11, p.85. (In Chinese)

[7] R.G. Zheng. contemporary finance, (2010) No.1, p.89. (In Chinese)

[8] T.S. Zhang and H.W. Xiao. Industrial Technology Economy, (2015) No.10, p.99. (In Chinese)

[9] L.C. Huang, H.C. Zhang and X.Y. Li. China Science and Technology Forum, (2005) No.4, p.41. (In Chinese)

[10] B.M. Chen. Science and Technology and Industry, Vol. 6 (2006) No.6, p.22. (In Chinese) 